\title{
Parental Assistance to Children and Youth in Accessing Digital Media
}

\author{
Hedi Pudjo Santosa ${ }^{1}$ \\ ${ }^{1}$ Ilmu Komunikasi, Universitas Diponegoro, Indonesia \\ Corresponding Author's Email : hedipudjos@gmail.com
}

\begin{abstract}
There are many positive things that teenagers and children may benefit from digital media such as medium of education and entertainment, easy access towards information, and as connecting tools. However, digital media does not only bring positive impacts towards children and teenagers. Under the freedom of information access, there is also a high risk of teenagers to access inappropriate information such as violence, pornography, horror and so on. Because of this, parents should agree that the presence of information technology is not safe if used freely without supervision. But, even though parents experience concerns regarding the excessive use internet by their children, not many of them are aware about what role can parents play to prevent their children from becoming compulsive internet users. Therefore, this community development program is expected to be able to educate parents in assisting their children in using digital media through media literacy. The location of study and implementation of this community service is in Semarang, which will serve as a continuation of the previous community development regarding media literacy which been carried out by the Ministry of Communications in Semarang with focus target on parents of children and teenagers (elementary, middle, and high school children).
\end{abstract}

Keywords: digital media, children and teenagers, media literacy

\section{INTRODUCTION}

The development of technology and information has brought great impact on the development of mass media. The growth of mass media in Indonesia shows how integrated and inseparable media are with life in society. This development does not only affect the content of the media itself but also affects the consumption of the community in the media. In this current time, digital media has become an integral part of everyday life in the lives of children and adolescents; making it difficult to separate children and adolescents from digital media. The media has two impacts: positive and negative.

The development of technology makes the lives of adolescents integrated with digital media. However, curiosity of children and adolescents is a concern for parents in providing digital access to their children. The positive impact of technology and information are as a medium of education and entertainment, give easy access to information for teenagers, provide educational facilities, and entertainment. Unfortunately, the presence of information technology also has a 
negative impact through the ease of access to information. This increases the risk of adolescents to access inappropriate information to consume such as violence, pornography, horror and so on. Because of this reason, parents agree that the presence of information technology is not safe if used freely by children and adolescents.

Survey conducted by APJII (Indonesian Internet Service Providers Association) shows that children aged 10-14 years have accessed the internet.

"Interestingly, through this survey it was found that $100 \%$ of children aged 10-14 have accessed the internet". Henri said during a press conference in Jakarta. The vast world of the internet reaches all circles and it seems to raise concern, especially parents. Respondents on average (76.4\%) think that the internet is not safe for children to access. (https://www.brilio.net/serius/100-anak-usia-10-14tahun-di-indonesia-pengguna-internet-aman-kah-1610257.html)

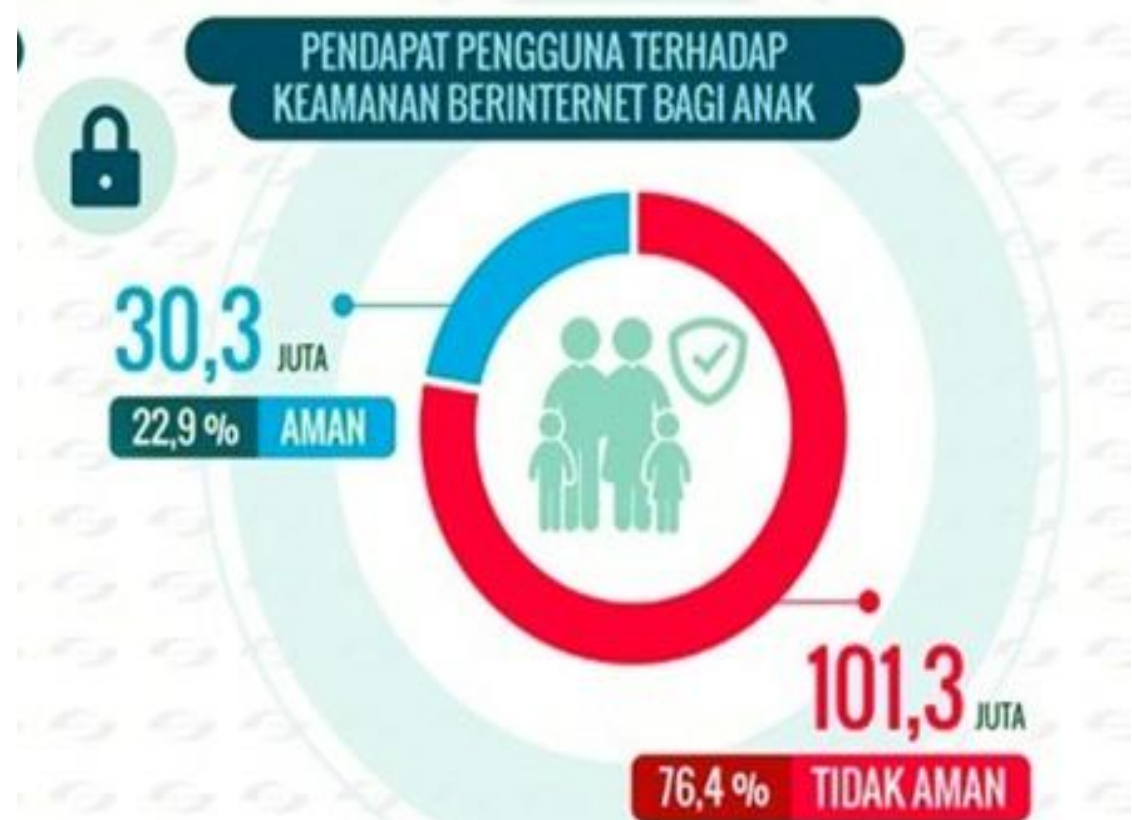

Picture 1. Opinion of Internet Users on Internet Safety for Children

ECPAT Indonesia reported the deviant facts that in 6 (six) Regencies/Cities in 2017, children are exposed to pornography through smart phones. The Indonesian Child Protection Commission also noted that of 4,500 junior and senior high school students in 12 cities, $97 \%$ of them accessed pornographic content (https://www.viva.co.id/gaya-hidup/parenting/1004277-97-persen-dari-4-500pelajar-smp-sma-akses-pornografi). 
Realized or not, children and adolescents are the most vulnerable targets to be affected by the content of information in the media. Television indirectly affects children by the raw information they received and consider it as real thing.

Youth according to Piaget (in Hurlock, 1980), psychologically, is the age where individuals integrate with adult society, the age where children no longer feel below the level of older people but are at the same level, at least in matters of rights. This type of typical intellectual transformation of thinking experienced by adolescents enables them to achieve integration in adult social relationships, which in fact is a common characteristic of this period of development.

When teenagers receive information in digital media, they accept it based on their perception. In addition to children, adolescents also fall into the category of being affected by this digital media. The existence of imitation behavior (imitating directly the behavior of people who are seen, heard, and read) becomes a problem in using digital media.

As quoted from the chairman of the Indonesian anti-hoax community statement in a press conference the declaration of the "Yojomase Anti-Defamation Society", on January 14, 2017 which then stated that:

"Many people are divided because they are influenced by hoaxes news, and hoaxes can accelerate physical unrest. News or hoax information is rife as one of the effects of the development of cyber civilization. Almost every person has a digital device and can access any information from their cell phone. It is also found that as many as 130 million Indonesians are internet users via mobile devices. Unfortunately, the literacy culture in Indonesia is the second lowest in the world. Therefore, so the culture of sharing is not accompanied by the habit of reading." (quoted from liputan6.com/read/2828281/penyebab-orang-indonesia-rentan-percaya-hoax-dimedsos-terkuak).

When using digital media, assistance from parents is required. However, the results of research conducted in 2018 on "The Meaning of Digital Media Content among Teens and the Role of Parental Assistance" shows that parents do not have much role in averting information that happens to be received by their children. In fact, parents seem to be inactive in monitoring digital media content accessed by their teenage children; parents only answer when questions are asked by their children. Another form of assistance encountered during the study was an effort to limit the relations between adolescents and their gadgets; it is proven that even some parents gave their full permission to their children in accessing digital media. Overall, the process of communication that takes place between parents and teenagers can be interpreted as open to each other, especially in accessing information through gadgets. Unfortunately, this openness is not accompanied by the same point of view in interpreting media content. 


\section{LITERATURE REVIEW OR RESEARCH BACKGROUND}

The internet has become an important and prevalent part of teenagers' daily lives. In the book Teen and Media, Hernandez (2007: 33) states that teenagers use the internet to connect with their friends, download music, shop for the latest fashions, get to know more about their favorite pop stars, learn new languages, check sports match scores, complete homework, even to reveal their most personal secrets for people to read all over the world. Teenagers' high frequency in using media and the many media products that reach them creates two-way relationship (Hernandez, 2007: 13). Young people are very influenced by the content provided by the mass media; in return mass media also become very influenced by what teenagers want (Hernandez, 2007: 13).

The easiness to access internet and the rapid development of technology presents new problem for parents especially those with children in teenage age; concerning giving them protection from the bad impact of the modern age. Although parents experience concerns regarding the excessive use internet by their children, not many of them are aware about what role can parents play to prevent their children from becoming compulsive internet users (van den Eijnden et. All, 2010: 77). Research results from van den Eijnden et. all (2010: 77), mentions that good qualitative communication about internet use is one way for parents to prevent their teenage children to become compulsive internet users. In addition, parental reactions to excessive internet use and parental rules regarding internet usage content can also help prevent compulsive internet use. Strict regulations regarding the time of internet use, can actually increase compulsive tendencies. For this reason, assistance is needed when using digital media through media literacy.

Media literacy, according to Aufderheide (1992) (in Koltay, 2011: 212) identified as a movement designed to help to understand, produce and negotiate the meaning in the culture of images, words and sounds.

“A person's knowledge of media literacy - the ability to decode, evaluates, analyze and produce both printed and electronic media. The fundamental aim of media literacy is an important autonomy relationship for all media. Emphasis in media literacy training ranges widely, including information citizenship, aesthetic appreciation and expression, social advocacy, self-esteem, and consumer competence ". (Aufderheide, 1992)

Arnett (2007) explained two models in media literacy; the first is protectionist inoculation models, namely media education with aim to inhibit access to media content and media which considered dangerous, especially to children. The protectionist model for media education promotes strategies to look critically and increase parental control of the media to children.

The second model is open-access models in media literacy where it considers the importance of personal enjoyment in the use of media by individuals and groups, with the belief that the audience, including children, deliberately negotiate meaning and realize that media is built. The open access model aims to advance media literacy education from strong freedom of expression, and emphasize its broadest access to the use of media as the foundation of democratic society. This model supports relatively limited access to tools, content, and 
distribution, with implications for legal and policy related issues such as copyright, systematic media ratings, media ownership, and media formation of communities.

The main concepts that can be conveyed to children and teenagers in media literacy are as follows (Arnett, 2007):

1. Messages are constructions. Message is the result of construction that media is not a simple reflection of external reality. Media messages are the result of very careful creation as a result of several external considerations and determinants.

2. Media messages are constructed using a creative language with its own rules. Media messaging uses a system of symbols, music, narration and digital imaging to have a certain effect on the viewer.

3. Audiences actively interpret messages. People construct meaning when consuming media. Interpretation of messages varies depending on individual factors, such as the level of development, personal needs and so on.

4. The media has embedded values and points of view. Explicitly or implicitly, the media express certain ideologies by displaying certain perspectives, values and attitudes in what they display.

5. Media have commercial implications and exist within an economic context. Media literacy aims to provide awareness of how media content is influenced by commercial, political and other interests.

The Ontario Association for Media Literacy (AML) defines media literacy with an emphasis on aspects of education:

"Media literacy is concerned with developing information and critical understanding of the nature of mass media, the techniques used by them, and the impact of these techniques. This is education that aims to increase students' understanding and enjoyment of how the media work, how they produce meaning, how they are organized, and how they construct reality. Media literacy also aims to provide students with the ability to make media products "(Duncan, (2006) in Koltay, 2011: 212)

\section{METHODOLOGY}

Parental assistance to children and teenagers is an activity to increase public knowledge about good media consumption patterns so as to minimize the negative impact of using digital media. The study of mass media characteristics and their impact, both psychologically, socially, culturally and economically, one of which is on children and adolescents, is one of the topics widely discussed in several courses at the Department of Communication Social Sciences Universitas Diponegoro. The implementation of these activities is one form of social responsibility of the Study Program towards the surrounding community, and respectively as a concrete implementation of Tri Dharma in Higher Education.

The purposes of organizing the community development activity of "Parental Assistance to Youth in accessing Digital Media" are providing technical media literacy training to parents and providing understanding to parents about how to influence children in using media positively. The activity is expected to give 
benefits to improve public understanding of good media consumption patterns, so as not to cause negative effects especially to children and adolescent, especially the use of digital media. The implementation of the activity is significant in contributing data related to the pattern of media consumption by children and adolescent; especially the use of online media.

The primary public target for the implementation of this activity is parents of children and adolescents (school age) in the city of Semarang. This community development activity will be carried out in several stages, namely;

1. Creating Training Materials

In this stage, the Community Service Team produces various media education training materials for educators and parents.

2. Training and Assistance

This stage is the implementation of training for educators and parents that contains the concept of media education and the operationalization of the concept in the form of delivery of media education materials for children.

An evaluation to measure the success of this activity will be carried out by examining the participants' understanding of the assistance process carried out through media literacy.

\section{RESULTS AND DISCUSSION}

This chapter shall discuss about the result of research parental assistance to children and teenagers in accessing digital media. The research activity is carried out for teenagers in primary to secondary education and parents with various types of work.

The following are the results of the finding:

1. Media Provision by Parents for Teenagers

The results of the discussions and interviews conducted show that each family provides media facilities such as television, newspapers (although only found in a few families) and subscribe to the internet at their place of residence. As for searching for information, the most frequently used media in this time is the internet. Almost all informants provide internet facilities in their homes and all families use the internet to find information in their daily lives.

The use of each media for each family is relatively varied, but the answers that appear are dominated by as a means of finding information and entertainment. This statement was delivered by both parents and teenagers, although in teenagers there were also answers about completion purpose for their school assignments.

2. Media and Information Finding by Teenagers and Parents Although parents and teenagers stated that the internet for both of them lead to information and entertainment searches, it is certainly reasonable if the two components they consume are also different; besides the difference in duration, use of the media, as well as the target of their search were also 
different. The results of the discussion and question and answer show that every parent (especially the mother), knows the consumption patterns of their family's information search (husband and children).

Each informant explained that the media information available in the household and used by almost all informants is the internet; then followed by television and radio, whilst a newspaper is last on the list. In accessing these media, parents tend to use every available facility. Watching television, reading newspapers, and using the internet are habits that are practiced by parents in finding information whereas children tend to use the internet as a media to access information. The information most frequently accessed by parents is related to politics, economics, health, religion, and the latest news.

3. Meaning of Digital Media Content In Teenagers And Responds To Pornographic Content And Hoaxes

Some young informants, when asked about the duration of time accessing the gadget answered on average more than 5 hours per day. They admitted that the gadgets they generally got from their parents were used to access schoolwork and sometimes when accessing, pornographic advertisements and hoax news accidentally appear. Upon responding to this event, teenagers responded differently.

4. Trust in Information Received Through The Media

Teenagers (informants) do easily trust in information received through the media both accessed by using the internet and conventional information, such as newspapers and radio; especially when it comes to hoaxes. The same result can be said when it comes to on porn sites that often appear in YouTube advertisements that they see. Teenagers can be concluded as party who are relatively capable of dealing with these conditions.

5. Parental Assistance In The Search Of Information In The Media By Teenagers

In this study, one-sided mentoring was surprisingly found where limit was created by parents through making rules for their children even though they said "only for supervising". Assistance will be better if previously discussed mutual understanding that is built based on the wishes of parents by paying attention to the needs of children.

\section{CONCLUSION}

Informants can be concluded as relatively smart in managing hoax news or fake news that they encounter when surfing in the cyberspace. This is a proof if they are capable enough to verify some information that they do not believe to be true. Unfortunately the role of parental assistance seems to be passive in monitoring 
digital media content accessed by teenagers; parents only provide answers when questions arise from teenagers.

Not much parental participation in warding off information that happens to be accessed by their teenagers. Another form of assistance that was encountered during the research is the effort to limit the relationship between teenagers with the gadget they have, even some parents gave full trust in their teenagers. Overall, the communication process that takes place between parents and teenagers can be interpreted as open to each other, especially in accessing information through gadgets. Unfortunately this openness is not followed by the same perception in interpreting media content.

The practice of digital media consumption by teenagers in this time is clearly something that is considered natural and common. So that it can be said it is unavoidable by teenagers. The number of negative content, such as pornographic content and hoax information, makes information in digital media to be hostile for teenagers.

Therefore, young people are expected to be more sensitive in receiving information in digital media and doing a crosscheck in every information received. There needs to be a role for mentoring or media literacy by parents when teenagers interpret existing digital media content. The form of media literacy that is openaccess becomes hope for parents and teenagers in negotiating existing meanings and democratic forms of assistance.

\section{BIODATA}

Dr. Hedi Pudjo Santosa is a lecturer of Communication Science Dept on Universitas Diponegoro, Semarang, Indonesia. He has a research interest in political communication and social communication.

\section{REFERENCES}

Arnett, Jeffrey Jensen edit. 2007. Encyclopedia of children, adolescents, and the media. London: Sage Publication. P. 526-529

Hernandez, Roger E. 2007. Gallup Youth Survey: Isu dan Tren Utama; Remaja dan Media. Terjemahan oleh Indri Yuli Astuti dan Wulandari. Bandung: PT Intan Sejati.

Hurlock, Elizabeth B. 1980. Psikologi Perkembangan: Suatu Pendekatan Sepanjang Rentang Kehidupan. Jakarta: Erlangga

Koltay, Tibor. 2011. Literacy The media and the literacies: media literacy, information literacy, digital.Journal Media,Culture \& Society,P. 210-222

Ruhaena, Lisnawati. 2015. Model Multisensori : Solusi Stimulasi Literasi Anak Prasekolah. Jurnal Psikologi. Hal : 47 - 60

(https://www.brilio.net/serius/100-anak-usia-10-14-tahun-di-indonesia-penggunainternet-aman-kah-1610257.html) 
(https://www.viva.co.id/gaya-hidup/parenting/1004277-97-persen-dari-4-500pelajar-smp-sma-akses-pornografi).

(liputan6.com/read/2828281/penyebab-orang-indonesia-rentan-percaya-hoax-dimedsos-terkuak). 